\title{
Effect of assay conditions on the measurement of dehydrogenase activity of Streptomyces venezuelae using triphenyl tetrazolium chloride
}

\author{
Tracey Burdock, Marianne Brooks", Abdel Ghaly, Deepika Dave
}

Department of Process Engineering and Applied Science, Dalhousie University, Halifax, Canada. Email: ${ }^{*}$ Su-Ling.Brooks@dal.ca

Received 9 April 2011; revised 19 June 2011; accepted 20 July 2011.

\begin{abstract}
Jadomycin is an antibiotic that has shown activities against bacteria, yeasts and fungi as well as cytotoxic properties to cancer cells. Because of the wide range of its inhibitory actions, jadomycin shows promise as a novel antibiotic and cancer treatment drug. Streptomyces venezuelae are aerobic bacteria that produce jadomycin and the size of bacterial population can significantly affect the yield of jadomycin. Therefore, the bacterial population must be accurately measured in order to standardize the reproducibility of jadomycin production process. In this study, a dehydrogenase activity measurement test, using triphenyl tetrazolium chloride (TTC), was used to measure the dehydrogenase activity of Streptomyces venezuelae during growth in maltose-yeast extract-malt extract (MYM) broth. The aims were to evaluate the effectiveness of the test for measuring microbial growth and to study the effects of the test conditions (incubation time, incubation temperature and medium $\mathrm{pH}$ ) on triphenyl formazan (TF) yield. The results showed that the TF yield was highly correlated to the optical density. The highest TF yield was observed at a pH of 6 at all incubation times and temperature. Lower TF yields were obtained at higher temperature $\left(40^{\circ} \mathrm{C}\right.$ and $\left.50^{\circ} \mathrm{C}\right)$ compared to those obtained at lower temperatures $\left(22^{\circ} \mathrm{C}\right.$ and $\left.30^{\circ} \mathrm{C}\right)$. The difference between the yields obtained at $22^{\circ} \mathrm{C}$ and $30^{\circ} \mathrm{C}$ were not significant. The differences between incubation time were also not significant. The recommended test conditions are an incubation time of 1 hour at a temperature of $30^{\circ} \mathrm{C}$ and a $\mathrm{pH}$ of 6 followed by three extractions using methanol.
\end{abstract}

Keywords: Dehydrogenase Activity; Growth; Triphenyl Tetrazolium Chloride (TTC); Triphenyl Formazan; Jadomycin; Streptomyces venezuelae; Temperature; $\mathrm{pH}$; Incubation Time

\section{INTRODUCTION}

Jadomycins are type II polyketide synthesis-derived secondary metabolites produced by the actinomycete Streptomyces venezuelae [1]. Jadomycins have demonstrated antibacterial, antitumor, antifungal and enzyme inhibitory functions as well as cytotoxic properties to the cancer cells [2]. They are considered to be promising novel antibiotics and cancer treatment drugs [3]. The production of jadomycin takes place in a nutrient-deprived (exhaustion of carbon, nitrogen or phosphate from the culture medium) amino acid rich environment assisted by environmental shock using ethanol or heat [4]. The formation of the cyclized product of jadomycin is due to the presence of amino acids in the culture medium which has a biosynthetic aldehyde precursor that generates a reactive aldimine to form jadomycin [5]. The production yield of jadomycin has been extensively linked to the mass of vegetative cells of Streptomyces venezuelae that is transferred from the growth medium to production medium [6]. Therefore, it becomes essential to determine the viable cell mass of Streptomyces venezuelae in growth media for the improvement and regularization of the reproducibility of the jadomycin production process.

Dehydrogenase activity measurement can be used for the determination of bacterial growth and metabolism [7]. The test is based on the fact that the dehydrogenase enzymes are produced by all living cells and the extend to which the enzymes oxidize organic matter can be related to the number of living cells during the growth phase and their activities during the production phase [8]. The dehydrogenase enzymes transport electrons and a hydrogen atom from an oxidized matrix to an electron acceptor $[9,10]$.

$$
\begin{aligned}
& \mathrm{RH}_{2} \stackrel{\text { Dehydrogenase }}{\longrightarrow} \mathrm{R}+2 \mathrm{H}^{+}+2 \mathrm{e} \\
& \text { substrate } \quad \begin{array}{c}
\text { Oxidized } \\
\text { substate }
\end{array}
\end{aligned}
$$


The dehydrogenase activity is largely measured using the triphenyl tetrazolium chloride (TTC) salt as a hydrogen acceptor $[11,12]$. TTC is a colourless salt which turns to a red triphenyl formazan (TF) dye as soon as it accepts hydrogen atoms. The TTC activity is determined colorimetrically by measuring the irreversible colour change (red color) during the reaction.

Different solvents are used for the extraction of TF from cells and the TF concentration is determined by measuring the optical density. The TF produced from the test is used as a measure of the amount of the living cells [8,13-15]. However, TF yield is depends upon several factors: type of solvent, number of extractions, incubation time, incubation temperature, and medium $\mathrm{pH}$ [16]. The purpose of this study was to evaluate the effects of assay conditions (medium $\mathrm{pH}$, incubation time and incubation temperature) on dehydrogenase activity and the TF yield from $S$. venezuelae.

\section{MATERIALS AND METHODS}

\subsection{Reagents}

Tris (hydroxymethyl)-aminomethane and triphenyl tetrazolium chloride (TTC) were used to measure the dehydorogenase activity. A TTC-glucose reagent $(1 \mathrm{~g}$ glucose and $2 \mathrm{~g}$ TTC dissolved in $100 \mathrm{~mL}$ distilled water) was prepared and stored in the dark at $4^{\circ} \mathrm{C}$ until used. Triphenyl formazan (TF) dye was used to establish a standard curve for absorbance $\left(O D_{484}\right)$ vs. TF concentration. $\mathrm{NaOH}$ and $\mathrm{HCl}$ were used to adjust the $\mathrm{pH}$ of the sample. Ethanol and methanol were used to extract the TF from bacterial cells. The Tris, TTC, TF, ethanol, methanol, $\mathrm{NaOH}$ and $\mathrm{HCl}$ were obtained from Sigma-Aldrich (Oakville, Ontario, Canada) and glucose was obtained from BioShop (Burlington, Ontario, Canada). Ethanol and methanol were obtained from Fisher Scientific (Montreal, Quebec, Canada).

\subsection{Media Preparation}

Maltose-yeast extract-malt extract (MYM) agar and broth were used to cultivate Streptomyces venezuelae. The composition of MYM agar and broth are shown in
Table 1. MYM media components.

\begin{tabular}{ccc}
\hline \multirow{2}{*}{ Component } & \multicolumn{2}{c}{ Quantity(g/L distilled water) } \\
\cline { 2 - 3 } & Agar & Broth \\
\hline Maltose & 4.0 & 4.0 \\
Yeast Extract & 4.0 & 4.0 \\
Malt Extract & 10.0 & 10.0 \\
MOPS & 1.9 & 1.9 \\
Agar & 15.0 & - \\
\hline
\end{tabular}

Table 1. All media components were obtained from BioShop (Burlington, Ontario, Canada). The media components were dissolved in the distilled water then autoclaved (SterileMax, Harvey Thermo Fisher Scientific, Ottawa, Ontario, Canada) on the liquid setting $\left(121^{\circ} \mathrm{C}\right.$, $20 \mathrm{~Pa}$ ) for 15 minutes. The autoclaved agar was stored at $65^{\circ} \mathrm{C}$ to prevent solidification

\subsection{Bacteria}

An initial starter plate of Streptomyces venezuelae ISP5230 was obtained from the Brooks Biotechnology Laboratory, Faculty of Engineering, Dalhousie University (Halifax, Nova Scotia, Canada) and stored at $4^{\circ} \mathrm{C}$. The surface growth was used to inoculate maltose-yeast extract-malt extract (MYM) agar plates or flasks with MYM broth.

\subsection{Triphenyl Formazan (TF) Standard Curve}

A standard curve was developed to determine the concentration of $\mathrm{TF}(\mu \mathrm{mol} / \mathrm{mL})$ corresponding to an absorbance measurement at $484 \mathrm{~nm}$ (OD484). A stock solution of $0.2 \mu \mathrm{mol} / \mathrm{mL}$ was prepared by dissolving $0.03 \mathrm{~g}$ $\mathrm{TF}$ in $500 \mathrm{~mL}$ methanol. The stock solution was diluted with methanol to produce 11 solutions with TF concentrations ranging from 0.004 to $0.10 \mu \mathrm{mol} / \mathrm{mL}$. The absorbance of each solution was measured with a spectrophotometer (Genesys 20, Thermo Scientific, Mississauga, Ontario, Canada) at a wavelength of $484 \mathrm{~nm}$. The absorbance readings $\left(O D_{484}\right)$ were plotted against the TF concentration $(\mu \mathrm{mol} / \mathrm{mL})$ as shown in Figure 1. The following linear best-fit Equation $\left(\mathrm{R}^{2}=0.98\right)$ was obtained:

$$
O D_{484}=10.574 \mathrm{TF}
$$

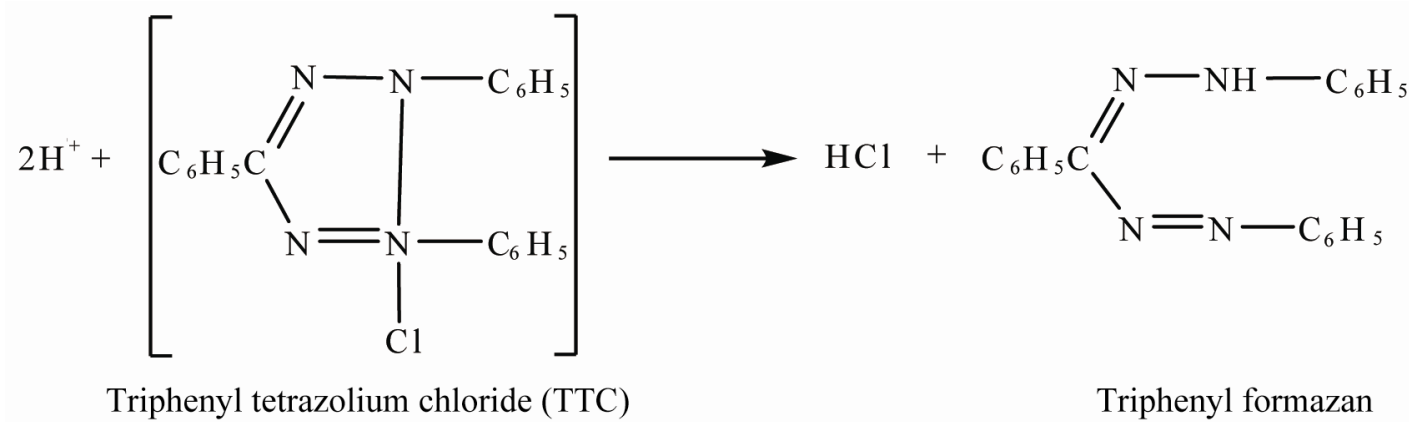


where:

$O D_{484}$ is the absorbance reading at $484 \mathrm{~nm}$ (AU)

$\mathrm{TF}$ is the concentration of triphenyl formazan $(\mu \mathrm{mol} /$ $\mathrm{mL}$ of extraction solvent)

\subsection{Bacterial Growth}

Three $250 \mathrm{~mL}$ shake flasks were filled with $175 \mathrm{~mL}$ of MYM broth, plugged with foam caps, covered with aluminum foil and autoclaved (SterileMax, Harvey Thermo Fisher Scientific, Ottawa Ontario, Canada) for $15 \mathrm{~min}$ utes at $121^{\circ} \mathrm{C}$ and $20 \mathrm{~Pa}$. The flasks were then inoculated with $S$. venezuelae and incubated in a controlled environment shaker (25 Incubator Shaker, New Brunswick Scientific, Edison, New Jersey, USA) at $30^{\circ} \mathrm{C}$ and 250 rpm. Each flask was sampled at $0,2,12,14,17,20,22$, $37,40,42,62$ and 64 hours after inoculation and the extent of cell growth was monitored over a period of 64 hours by measuring the optical density at $600 \mathrm{~nm}\left(O D_{600}\right)$ and the dehydrogenase activity (TF yield).

To measure the dehydrogenase activity at each sampling time, an aliquot of $1 \mathrm{~mL}$ was transferred from each flask into each of the four test tubes (three replicates and control). The $\mathrm{pH}$ was adjusted to 7.5 using $1 \mathrm{~N} \mathrm{NaOH}$ or $\mathrm{HCl}$. Tris buffer $(2.5 \mathrm{~mL})$ was added to the all test tubes. This was followed by $1 \mathrm{~mL}$ of TTC/glucose solution added to the three sample test tubes whereas $1 \mathrm{ml}$ distilled water added to control tube. The tubes were gently swirled to mix the contents, incubated at $50^{\circ} \mathrm{C}$ for 1 hour in a temperature controlled oven (Isotemp Oven, Model 630F, Fisher Scientific, Ottawa, Ontario, Canada) and then centrifuged (IEC Centra CL2, Thermo Electron Corporation, Mississauga, Ontario) for 10 minutes to separate the cells from the liquid media. The supernatant was discarded and $2.5 \mathrm{~mL}$ of methanol was added to the cells in the tubes. All tubes were vortexed (Thermolyne Maxi Mix, Thermolyne Corporation, Hampton, New Hampshire, USA) to aid in the extraction of TF from the cells. Samples were centrifuged again and the supernatant decanted. Two more extractions with methanol were carried out as recommended by Burdock [17] and the supernatants were combined with that from the first extraction. The absorbance of three combined supernatant extractions was measured at $484 \mathrm{~nm}$ in a spectrophotometer (Genesys 20, Thermo Scientific, Mississauga, Ontario, Canada). The control test tube was used to adjust the spectrophotometer to zero. The TF yield was then determined using Eq.3.

\subsection{Evaluating the Test Parameters}

Experiments were conducted to determine the effect of test conditions on the reduction of TTC to TF and the optimum combination that allow the extraction of the highest amount of TF from $S$. venezuelae during growth in MYM media. The dehydrogenase activity assay pa-

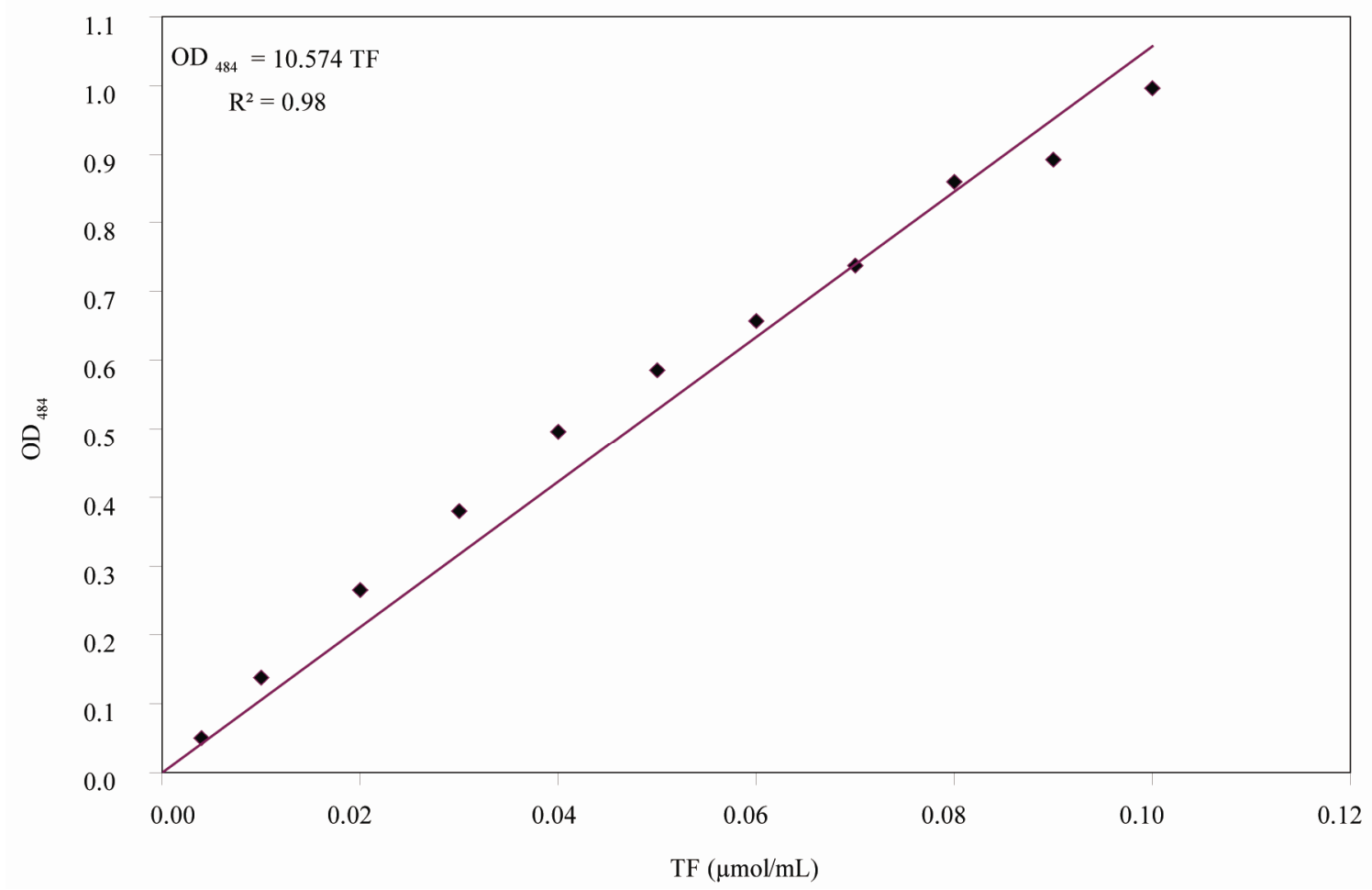

Figure 1. Standard curve relating TF concentration to absorbance at $484 \mathrm{~nm}(\mathrm{n}=3)$. 
rameters investigated were: incubation time $(1,2,3$ and $4 \mathrm{~h})$, incubation temperature $\left(22^{\circ} \mathrm{C}, 30^{\circ} \mathrm{C}, 40^{\circ} \mathrm{C}\right.$ and $50^{\circ} \mathrm{C}$ and medium $\mathrm{pH}(6.0,7.5$ and 9.0). Three extractions with methanol were carried out as recommended by Burdock [17]. The experiments were carried out in completely randomized factorial design $(3 \times 4 \times 4)$ with three replicates, resulting in 144 experimental runs. The contents of all flasks were collected after 64 hours of growth, combined in a $1 \mathrm{~L}$ flask and refrigerated at $4^{\circ} \mathrm{C}$ until required. For a given incubation temperature-medium $\mathrm{pH}$ - incubation - time combination, a $1 \mathrm{~mL}$ aliquot of the MYM broth containing S. venezuelae growth was added to each of four test tubes (three replicates and a control). The $\mathrm{pH}$ was adjusted to the desired value $(6,7$ or 9) using $1 \mathrm{~N} \mathrm{HCl}$ or $\mathrm{NaOH}$. Tris buffer $(2.5 \mathrm{~mL})$ and TTC/glucose solution $(1 \mathrm{~mL})$ were added to each of the three sample test tubes whereas $1 \mathrm{ml}$ distilled water was added to control tube. The tubes were manually swirled to mix contents and incubated for the assigned time $(1,2$, 3 or 4 hours) at the desired temperature $\left(22^{\circ} \mathrm{C}, 30^{\circ} \mathrm{C}\right.$, $40^{\circ} \mathrm{C}$ or $50^{\circ} \mathrm{C}$ ). Tubes were incubated at $22^{\circ} \mathrm{C}$ or $30^{\circ} \mathrm{C}$ in an environment controlled incubator (Model 2020, VWR International, Cornelius, Oregon, USA) and at $40^{\circ} \mathrm{C}$ or $50^{\circ} \mathrm{C}$ in a temperature controlled oven (Isotemp Oven, Model 630F, Fisher Scientific, Ottawa, Ontario, Canada). Samples were then centrifuged for 10 minutes to separate the cells from the liquid media. The supernatant was discarded and extraction of TF from the cells was carried out using $2.5 \mathrm{~mL}$ methanol. Three extractions were carried out and the supernatants from the three extractions were combined. The absorbance was then measured at $484 \mathrm{~nm}$ in a spectrophotometer (Genesys 20, Thermo Scientific, Mississauga, Ontario, Canada). The control test tube was used to adjust the spectrophotometer to zero. The TF yield was then determined using Eq.3.

\section{RESULTS}

\subsection{Bacterial Growth}

The growth of $S$. venezuelae as measured by the optical density at $600 \mathrm{~nm}\left(O D_{600}\right)$ and the triphenyl formazan yield (TF) is presented in Figure 2. The results showed an initial lag period followed by exponential growth. The lag period was required for the bacteria to adjust to the new environmental condition and to produce the enzyme required for the utilization of growth substrate in the medium. The lag period and specific growth rate were determined graphically according to the procedure described by Ghaly et al. [18] as shown in Figure 3. The lag period and specific growth rate were 10.3 hours and $0.3 \mathrm{~h}^{-1}$ respectively.

\subsection{Assay Parameters}

Figure 4 shows the effect of medium $\mathrm{pH}$ on the TF yield at varying incubation times and incubation temperatures. All plots displayed similar shapes with the $\mathrm{pH}$ value of 7.5 resulting in the lowest TF yield and the $\mathrm{pH}$ value of 6 resulting in the greatest TF yield. Figure 5 shows the effect of incubation time on the TF yield at varying incubation temperatures and medium $\mathrm{pH}$ values. The results showed slight increases in TF yield at longer incubation time. Figure 6 shows the effect of incubation temperature on the $\mathrm{TF}$ yield at different incubation times and medium $\mathrm{pH}$ values. The results showed that higher incubation temperatures $\left(40^{\circ} \mathrm{C}\right.$ and $\left.50^{\circ} \mathrm{C}\right)$ resulted in lower $\mathrm{TF}$ yields than these obtained at lower incubation temperatures $\left(22^{\circ} \mathrm{C}\right.$ and $\left.30^{\circ} \mathrm{C}\right)$.

Table 2 shows the analysis of variance performed out on the TF yield data. The medium $\mathrm{pH}$, incubation time and incubation temperature had significant effects on TF yield $(P<0.001)$ with $\mathrm{pH} 6$ having the highest TF yield. The two-way interactions ( $\mathrm{pH}$-Time, $\mathrm{pH}$-Temperature and Time-Temperature) were also significant $(P<0.008)$ but the three-way interaction was not significant. Table 3 shows the results of Duncan multiple range test performed on the TF data. All three levels of the medium $\mathrm{pH}$ were significantly different from one another $(\mathrm{P}<$ 0.05 ) with $\mathrm{pH} 6$ having the highest TF yield. The incubation temperatures of $22^{\circ} \mathrm{C}$ and $30^{\circ} \mathrm{C}$ were not significantly different from one another. Also, the incubation temperatures of $40^{\circ} \mathrm{C}$ and $50^{\circ} \mathrm{C}$ were not significantly different from one another. However, the lower temperatures $\left(22^{\circ} \mathrm{C}\right.$ and $\left.30^{\circ} \mathrm{C}\right)$ had significantly higher $\mathrm{TF}$ yield than the higher temperatures $\left(40^{\circ} \mathrm{C}\right.$ and $\left.50^{\circ} \mathrm{C}\right)$. All the four incubation times were not significantly different from one another.

\section{DISCUSSION}

\subsection{Bacterial Growth and Activity}

Jakeman et al. [6] monitored S. venezuelae population during the growth period by measuring the optical density at $600 \mathrm{~nm}\left(O D_{600}\right)$. In this study, the change of $S$. venezuelae population during the growth period was

Table 2. Analysis of variance for dehydrogenase activity test parameters.

\begin{tabular}{cccccc}
\hline Source & DF & SS & MS & F-Value & $\boldsymbol{P}$ \\
\hline Total & 143 & 49.5667 & & & \\
Model & 47 & 40.0942 & & & \\
$\mathrm{pH}$ & 2 & 10.9850 & 5.493 & 61.134 & 0.0001 \\
$\mathrm{t}$ & 3 & 1.6077 & 0.536 & 5.961 & 0.0010 \\
$\mathrm{~T}$ & 3 & 18.0770 & 6.026 & 67.066 & 0.0001 \\
$\mathrm{pH} \times \mathrm{t}$ & 6 & 1.9600 & 0.327 & 3.636 & 0.0030 \\
$\mathrm{pH} \times \mathrm{T}$ & 6 & 3.7340 & 0.622 & 6.927 & 0.0001 \\
$\mathrm{t} \times \mathrm{T}$ & 9 & 2.3770 & 0.264 & 2.939 & 0.0040 \\
$\mathrm{pH} \times \mathrm{t} \times \mathrm{T}$ & 18 & 2.2010 & 0.122 & 1.361 & 0.1700 \\
Error & 96 & 8.6250 & 0.090 & & \\
\hline
\end{tabular}

$\mathrm{pH}=$ Medium $\mathrm{pH} ; \mathrm{t}=$ Incubation Time (hours) $\mathrm{T}=$ Incubation Temperature $\left({ }^{\circ} \mathrm{C}\right) ; \mathrm{R}^{2}=0.83$. 


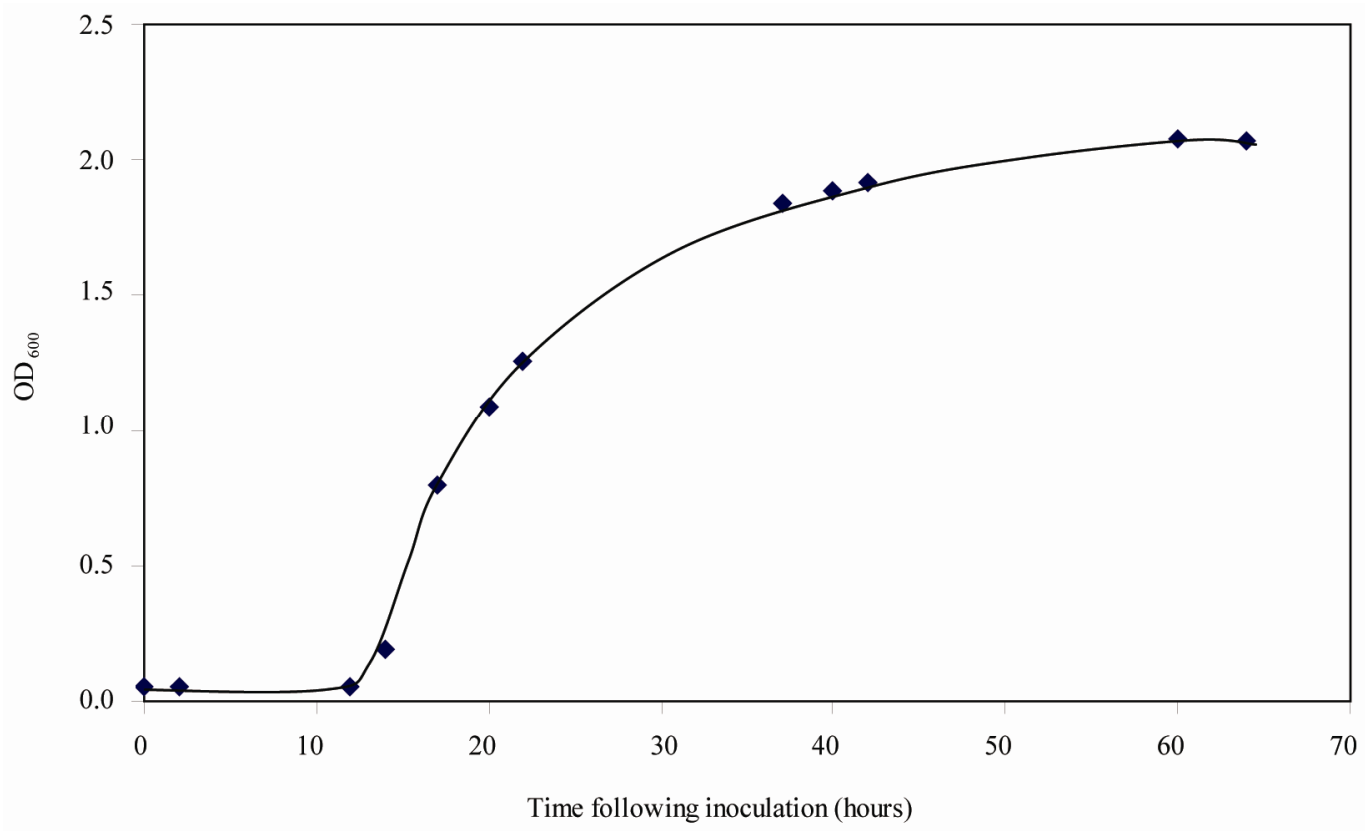

(a)

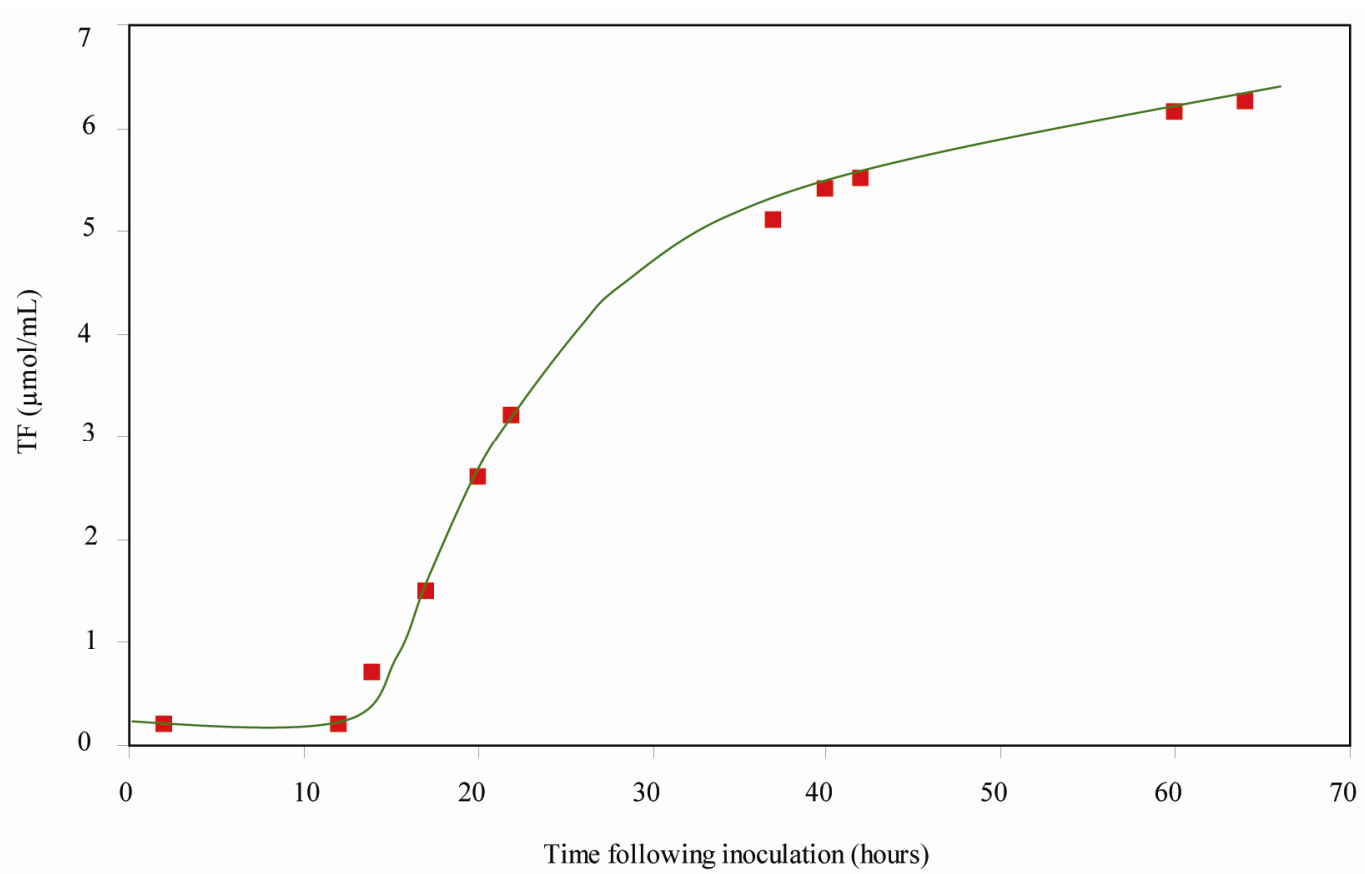

(b)

Figure 2. S. venezuelae growth in nutrient rich MYM broth as measured by optical density and TF yield.

monitored by measuring the optical density at $600 \mathrm{~nm}$ $\left(O D_{600}\right)$ and the triphenyl formazan yield (TF) (Table 4). The relationship between $O D_{600}$ and TF is presented in Figure 7. The amount of TF extracted was correlated $\left(\mathrm{R}^{2}\right.$ $=0.9833$ ) with $O D_{600}$.

The specific growth measured in this study was 0.3 $\mathrm{h}^{-1}$. Abdel-Fattah [19] reported maximum specific growth rates of 0.57 and $0.23 \mathrm{~h}^{-1}$ for $S$. venezuelae grown in media containing glucose and soluble starch at $30^{\circ} \mathrm{C}$, respectively. Glazebrook et al. [20] reported a maximum specific growth rate of $0.14 \mathrm{~h}^{-1}$ for $\mathrm{S}$. venezuelae grown in MYM medium at $27^{\circ} \mathrm{C}$.

\subsection{Assay Parameters}

A significantly acidic $\mathrm{pH}(1.5$ - 3) was found to result 


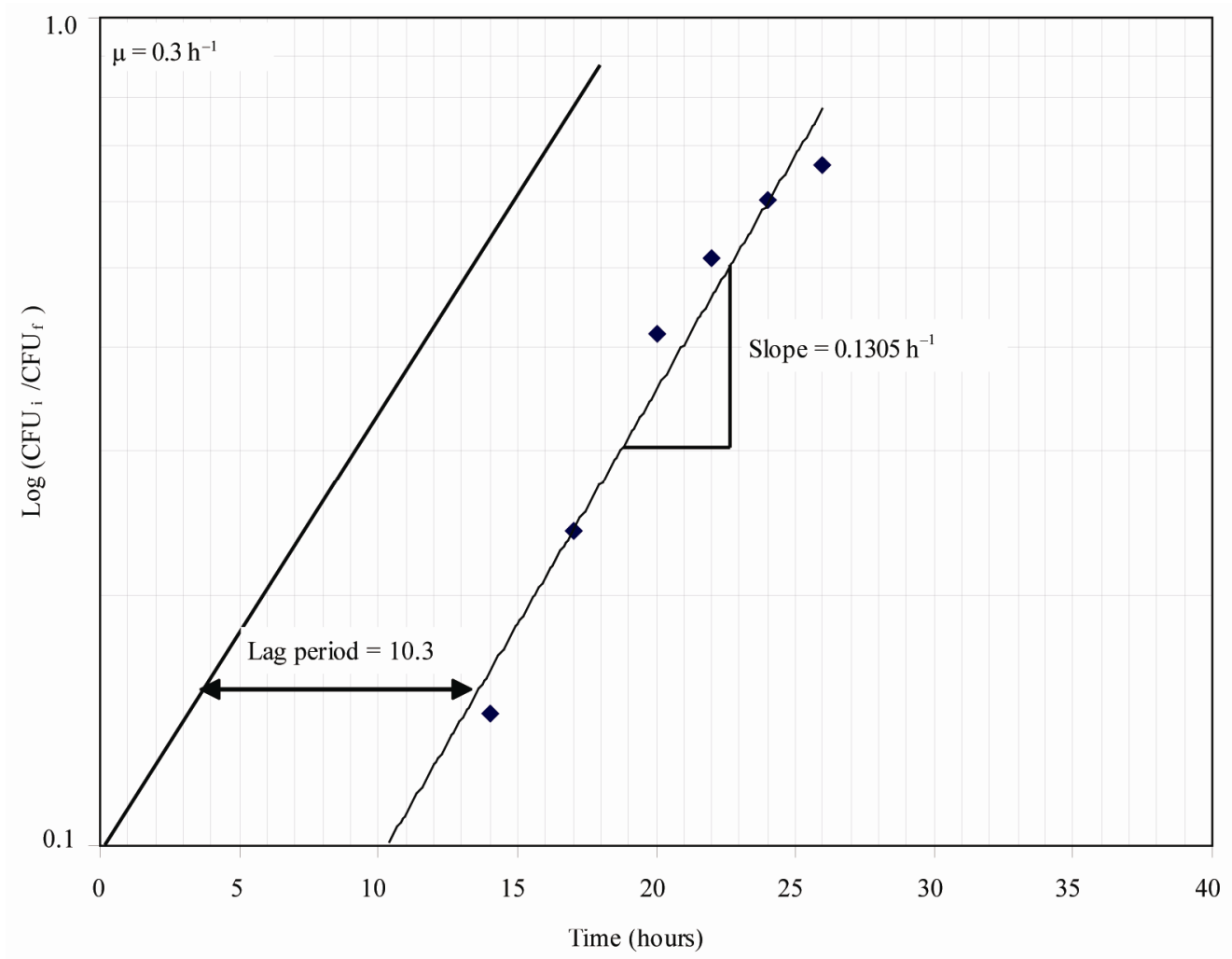

Figure 3. Graphical determination of the lag period and specific growth rate.

Table 4. Means of TF yield for $\mathrm{pH}$, incubation temperature and incubation time.

\begin{tabular}{cccc}
\hline Parameter & $\begin{array}{c}\text { Number of } \\
\text { observations }\end{array}$ & $\begin{array}{c}\text { Mean of } \\
\text { TF yield Grouping* }\end{array}$ \\
\hline $\mathbf{p H}$ & & & \\
6.0 & 48 & 1.195 & $\mathrm{~A}$ \\
7.5 & 48 & 0.525 & $\mathrm{~B}$ \\
9.0 & 48 & 0.780 & $\mathrm{C}$ \\
Incubation Temperature & & & \\
$\left({ }^{\circ} \mathbf{C}\right)$ & 36 & 1.240 & $\mathrm{~A}$ \\
22 & 36 & 1.101 & $\mathrm{~A}$ \\
30 & 36 & 0.632 & $\mathrm{~B}$ \\
40 & 36 & 0.359 & $\mathrm{~B}$ \\
50 & & & \\
Incubation Time (hours) & 36 & 0.693 & $\mathrm{~A}$ \\
1 & 36 & 0.804 & $\mathrm{~A}$ \\
2 & 36 & 0.843 & $\mathrm{~A}$ \\
3 & 36 & 0.988 & $\mathrm{~A}$ \\
\hline
\end{tabular}

*Means with different letters are significantly different from one another at $95 \%$ confidence level.

in higher TTC reduction in lichens [21]. No other reports for higher $\mathrm{TF}$ yields at acidic $\mathrm{pH}$ were found in the literature. However, higher TF values are always associated with natural or slightly alkaline conditions. Mahmoud and Ghaly [13] found that at a $\mathrm{pH}$ of less than 7, no reduction of TTC occurred for Kluyveromyces fragilis growing in cheese whey and mixed culture growing in compost materials. Jones and Prasad [22] measured slu- dge activity and noticed a considerable amount of TTC reduction at $\mathrm{pH} 7.6$ compared to $\mathrm{pHs} 3.2$ and 5.3. Mersi and Sehinne [23] reported optimal iodonitrotetrazolium chloride (INT) reduction in soils at $\mathrm{pH}$ 7.0. Brzezińska et al. [24] observed maximum dehydrogenase activity in soils at $\mathrm{pH}$ of 6.6 - 7.2. Ghaly and Ben-Hassan [25] found maximum dehydrogenase activities for both Kluyveromyces fragilis and Candida pseudotropicalis yeast at a $\mathrm{pH}$ of 7 and lower activities at the more acidic and basic levels of $\mathrm{pH}$. Higher TF yield was observed at a $\mathrm{pH}$ of 9 for A. niger by Ghaly and Mahmoud [26]. However, at high $\mathrm{pH}$ values non-enzymatic reduction of TTC to TF may also occur [13]. It is not clear if non-enzymatic reduction of TTC to TF occurred at a $\mathrm{pH}$ of 9 in this study. The results indicated that a $\mathrm{pH}$ of 6 is the most appropriate value for measuring dehydrogenase activity in S. venezuelae during growth in MYM broth.

Several investigators reported that incubating samples for longer times increased the extent of TTC reduction to TF. Mahmoud and Ghaly [27] reported that TF yield increased exponentially with incubation time for A. niger in the range of incubation periods studied (1.5 - 4.5 hours). Ghaly and Ben-Hassan [25] found that the TF yield increased with increased incubation time for both Kluyveromyces fragilis and Candida pseudotropicalis yeast cells, but appeared to plateau after about 80 hours in 

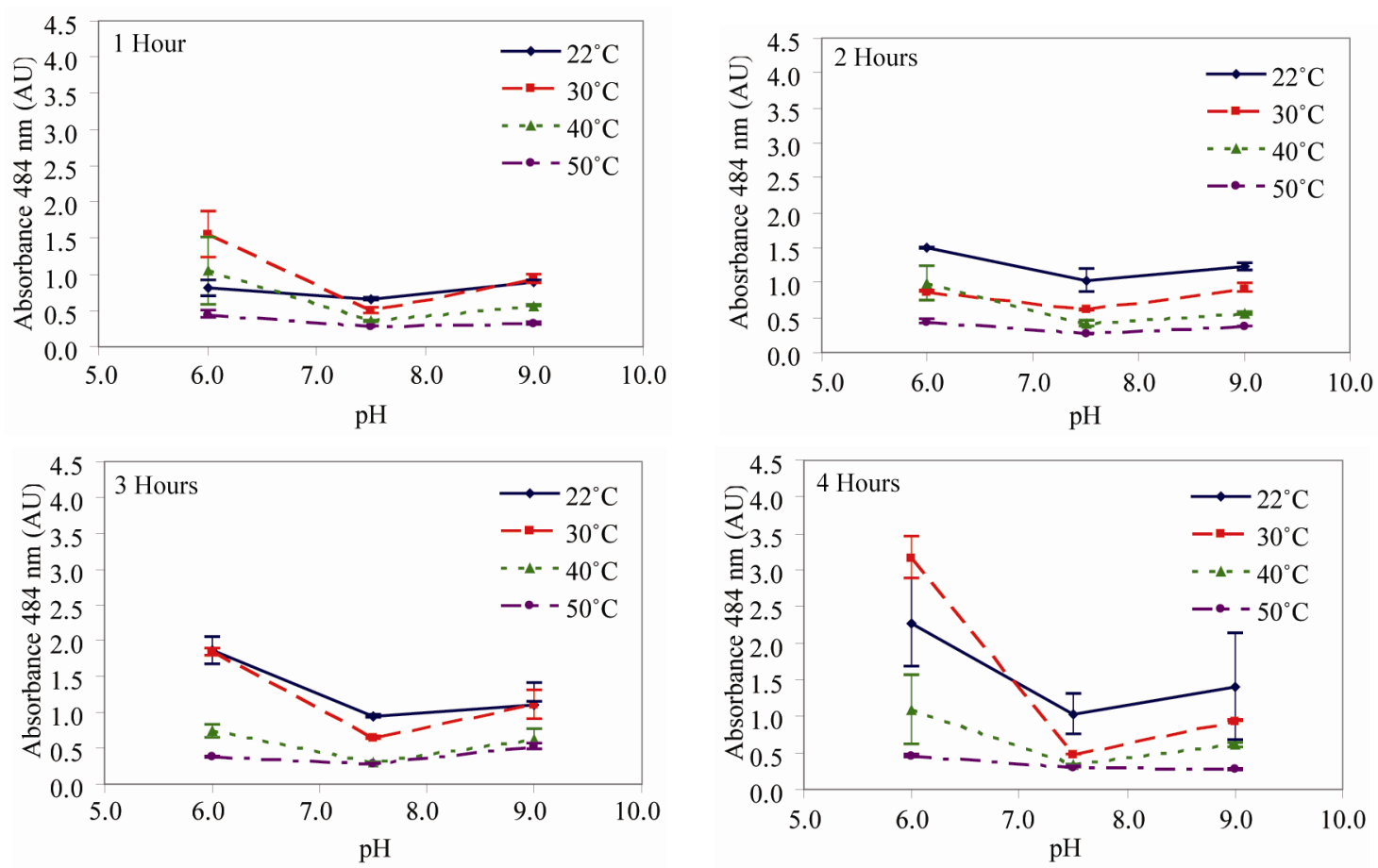

(a)
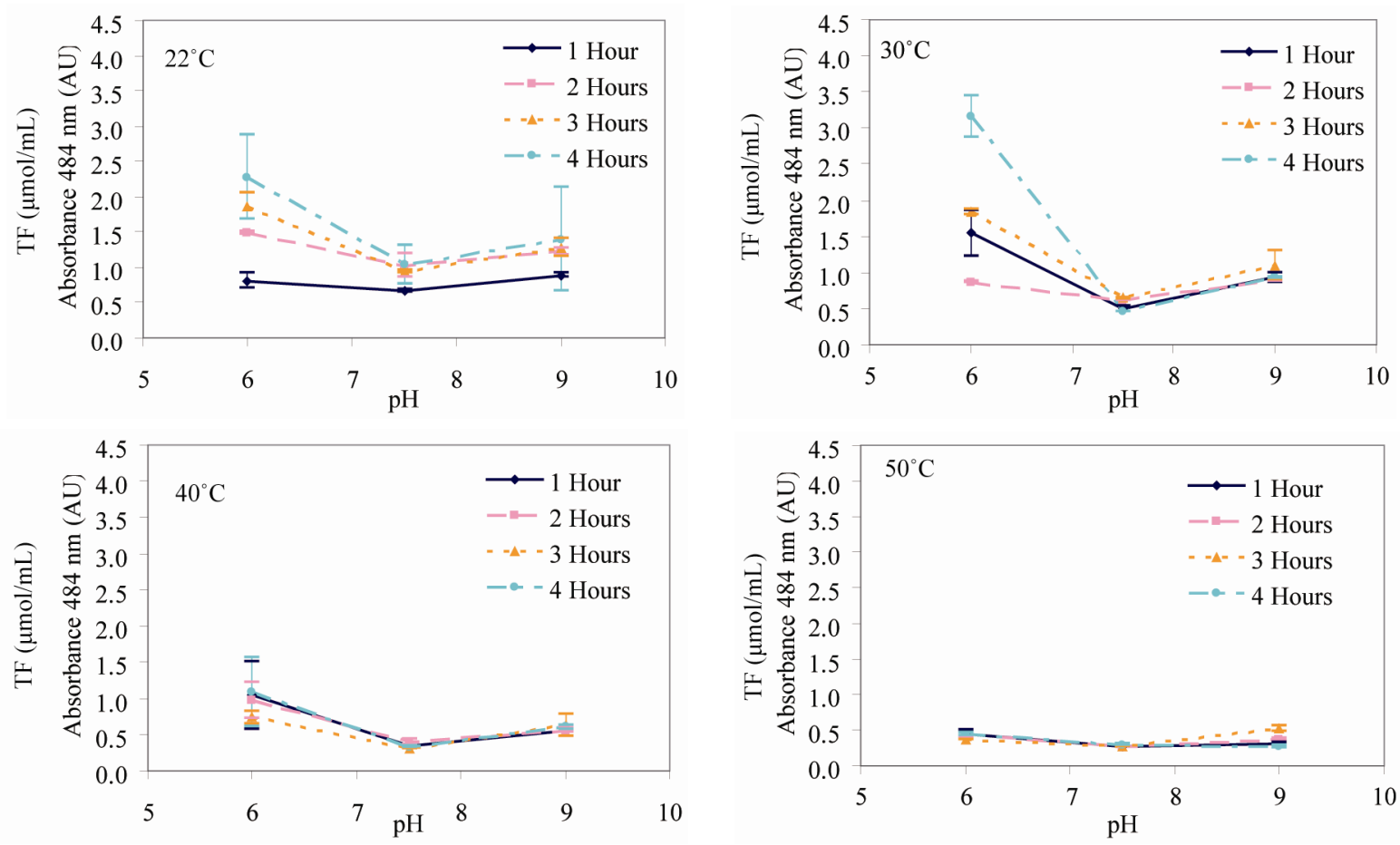

(b)

Figure 4. Effect of $\mathrm{pH}$ on triphenyl formazan formation (TF) at various incubation temperatures and times. (a) Incubation Time; (b) Incubation Temperature.

both cases. Mathew and Obbard [28] reported increasing INT-formazan yield with increased incubation time for petroleum-contaminated beach sediments and observed leveling off of TF yield after 22 hours of incubation. Tengerdy et al. [29] reported increasing TF yield of $E$. coli and $S$. aureus cultures during a 30 hours incubation 

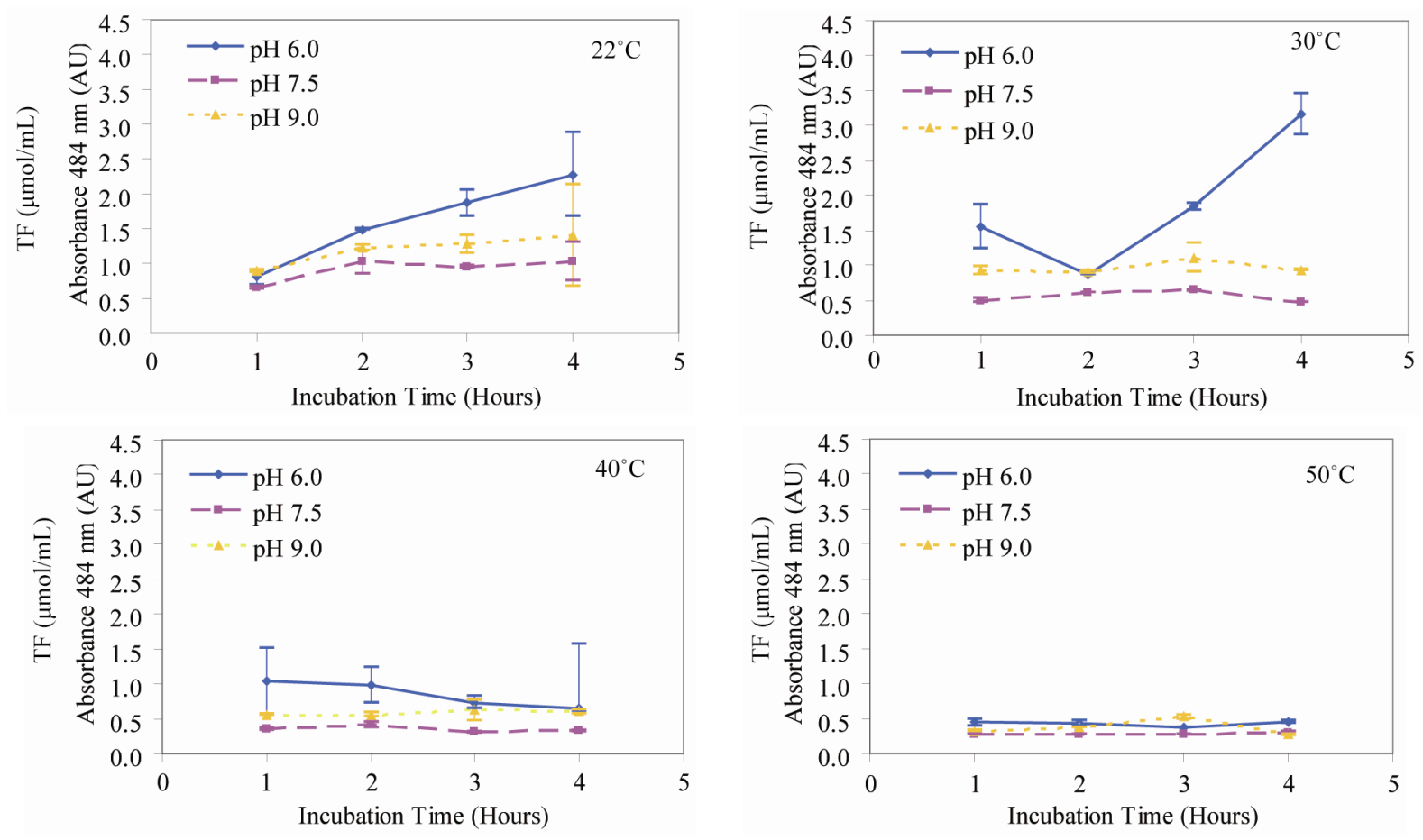

(a)
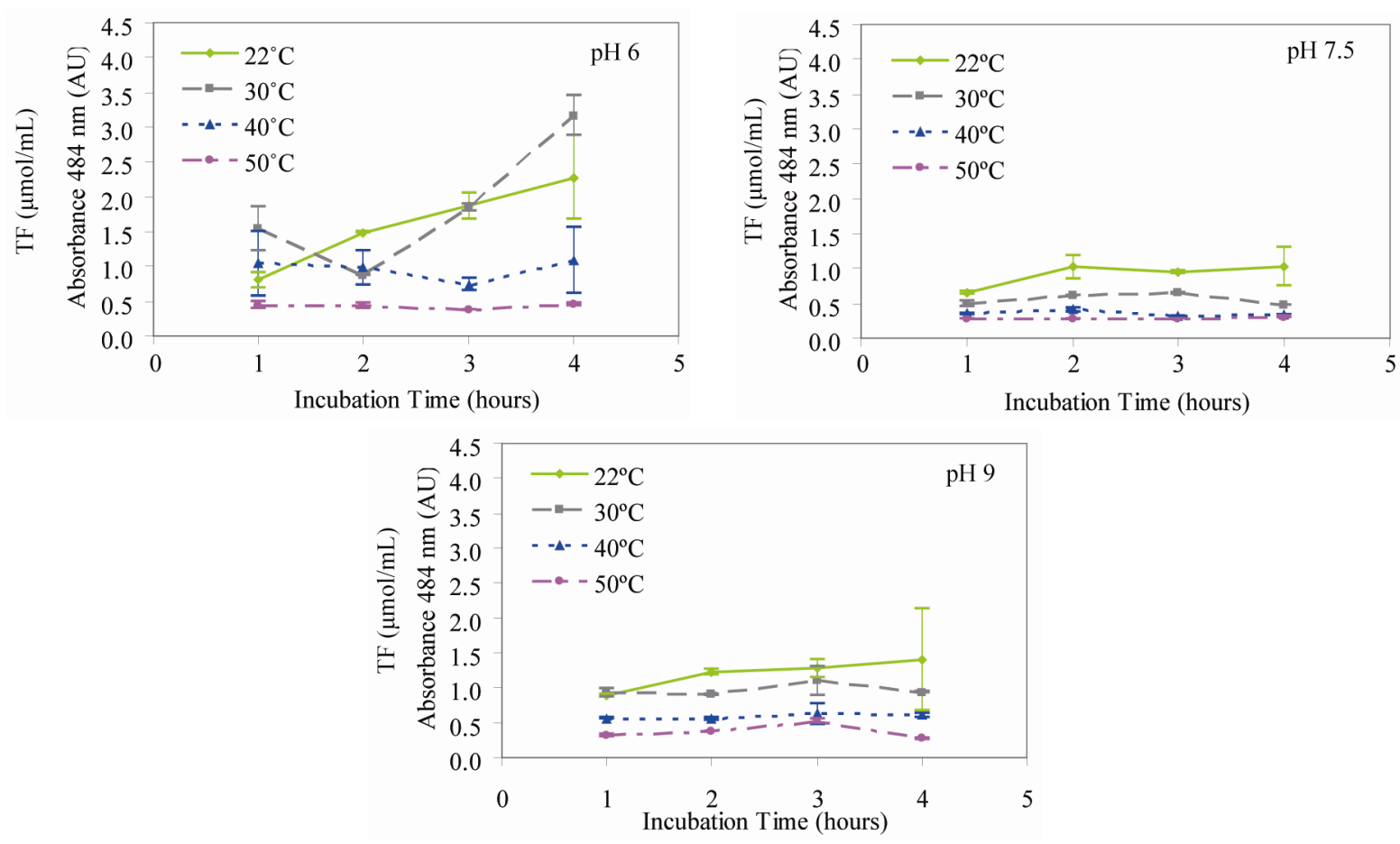

(b)

Figure 5. Effect of incubation time on triphenyl formazan (TF) formation at various incubation temperatures and medium $\mathrm{pH}$ values. (a) Incubation Temperature; (b) Medium pH Value.

period and observed stationary yield of TF after 30 hours. Griebe et al. [30] incubated activated sludge for a period of 24 hours with redox-sensitive dye 5-cyano-2,3-ditolyl tetrazolium chloride (CTC) and found no further increase in fromazan yield after 2 hours of incubation. In this study, a slight increase in TF yield from S. venezue- 

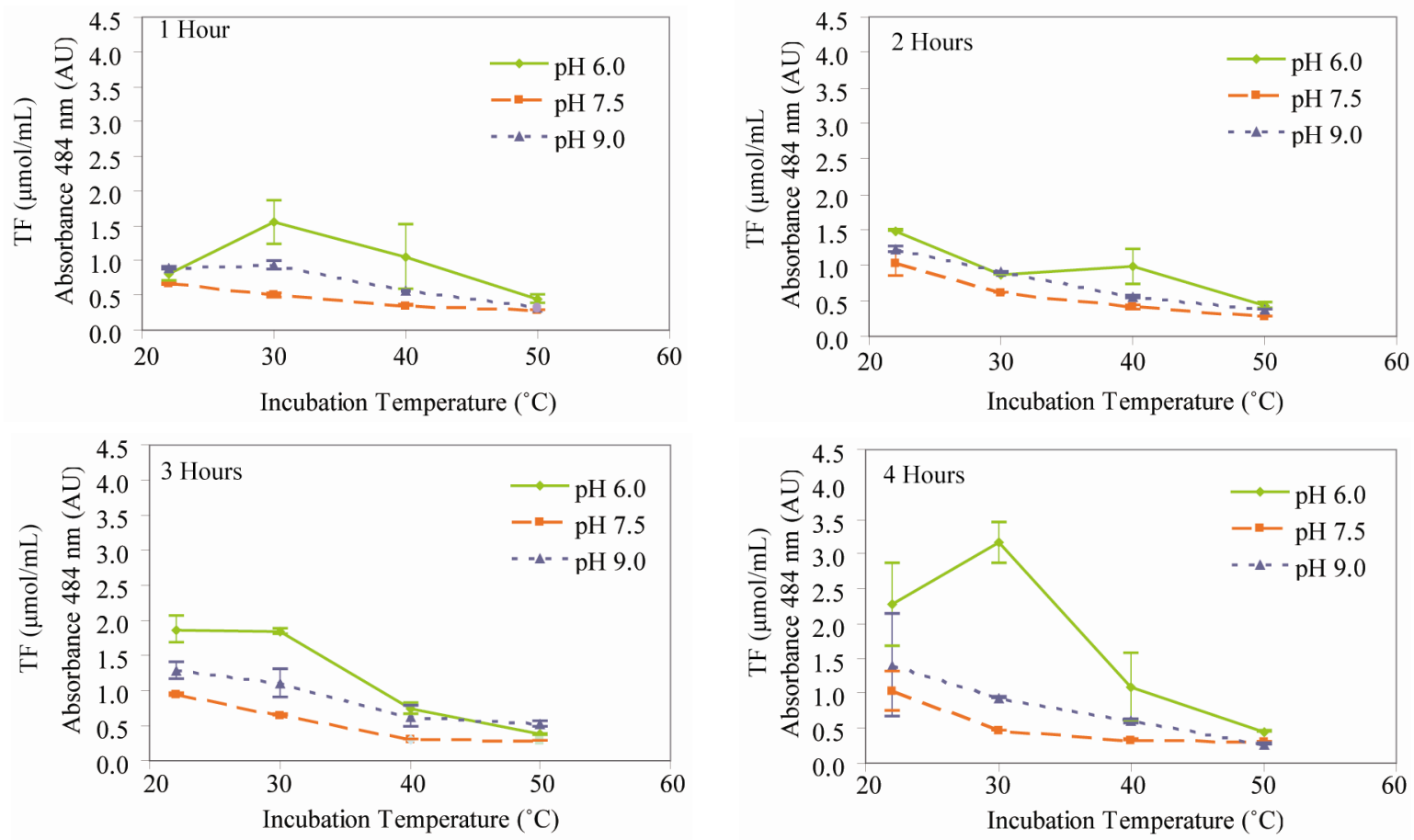

(a)
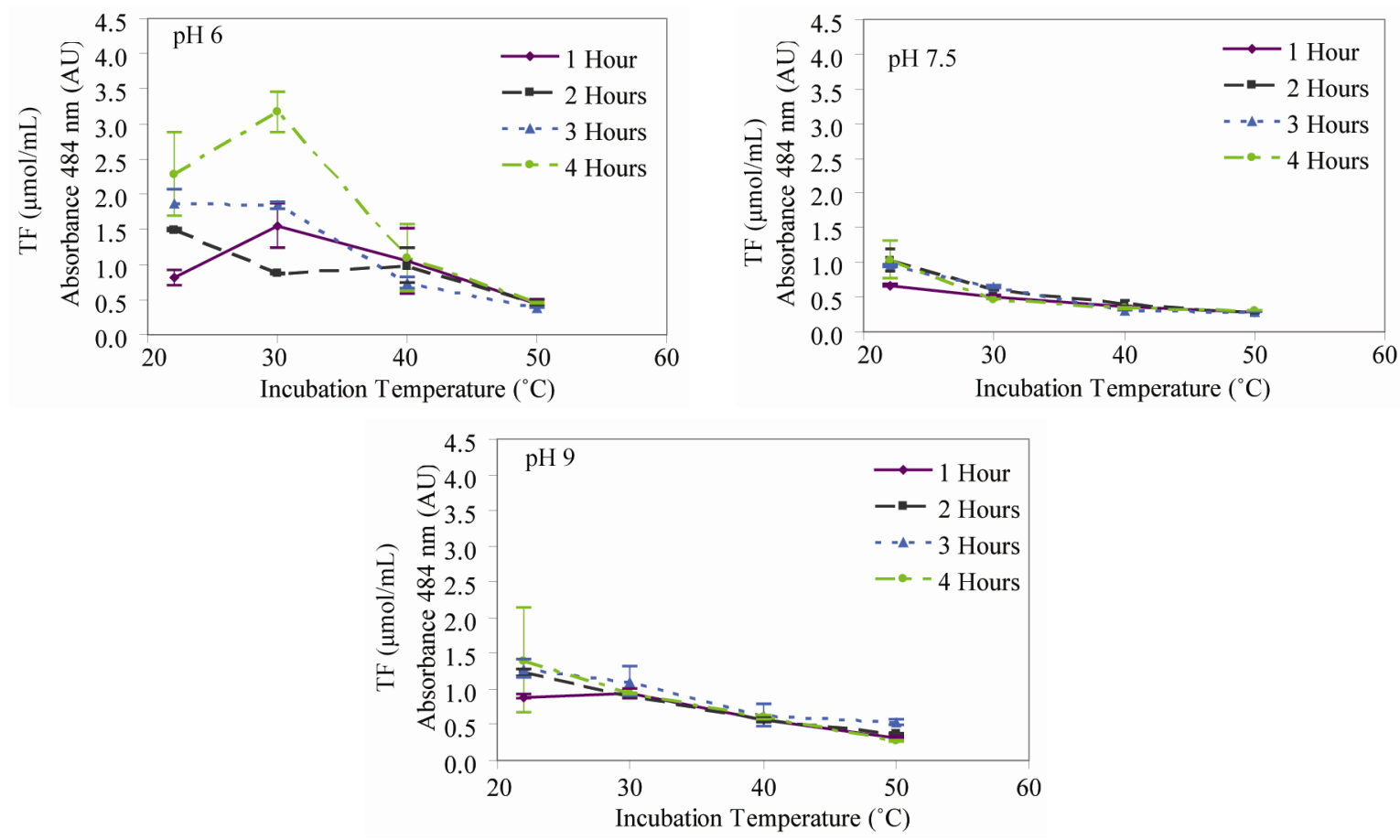

(b)

Figure 6. Effect of incubation temperature on triphenyl formazan (TF) formation at different incubation times and medium $\mathrm{pH}$ values. (a) Incubation Time; (b) Medium $\mathrm{pH}$ Value.

lae was observed when the incubation time was increased from 1 to $4 \mathrm{~h}$. It also, appears that longer incubation times are required for lower temperatures $\left(22^{\circ} \mathrm{C}\right.$ and $30^{\circ} \mathrm{C}$ ) compared to those required for higher temperatures $\left(40^{\circ} \mathrm{C}\right.$ and $\left.50^{\circ} \mathrm{C}\right)$. However, the increases in $\mathrm{TF}$ yield observed in this study due to increase in incubation 


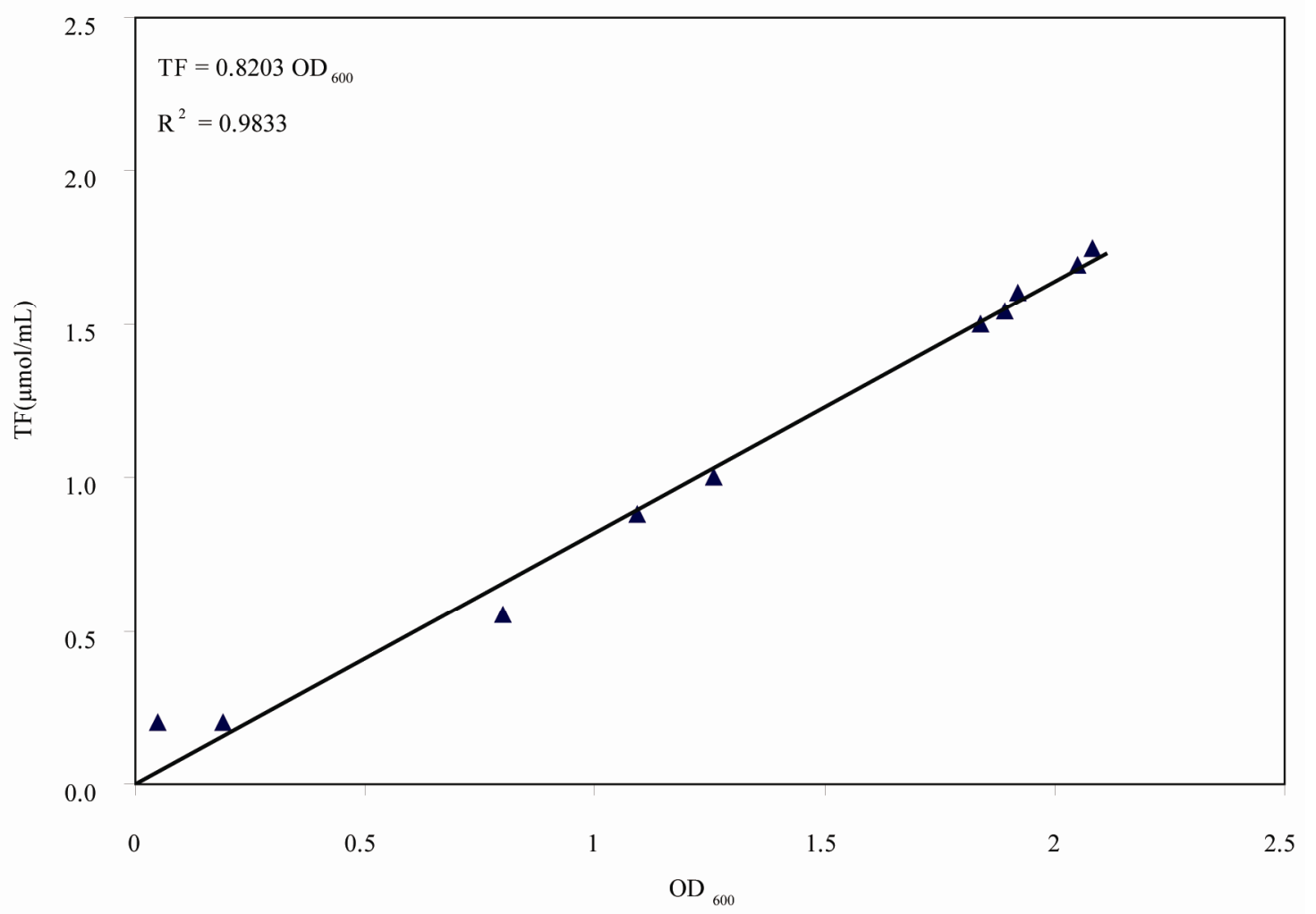

Figure 7. The relationships between $\mathrm{OD}_{600}$ and TF.

time do not appear to be significant and 1 hour incuba$\S$ tion time seems to be more practical as it produced a measurable amount of TF.

There have been reports in the literature of higher TF yields as a result of increasing incubation temperatures for mixed microbial populations in soil [31] and for the fungus A. niger in chitin [27]. Mersi and Sehinne [23] reported that increases in incubation temperature from $25^{\circ} \mathrm{C}$ to $40^{\circ} \mathrm{C}$ significantly increased the dehydrogenase activity but further increases in incubation temperature to $50^{\circ} \mathrm{C}$ resulted in a rapid decrease of Iodonitrotetrazolium Chloride (INT) reduction. Tiquia et al. [32] reported the highest level of dehydrogenase activity in yard trimming composting at temperatures in the range of $30^{\circ} \mathrm{C}-35^{\circ} \mathrm{C}$. Xie et al. [8] reported that the maximum $\mathrm{TF}$ yield of algae (Chlorella algae) in fresh water was reached at a temperature of $32^{\circ} \mathrm{C}$. Zhao et al. [33] reported higher (107 folds) dehydrogenase activity for heavy metal-organic contaminated sewage river sediment at incubation temperature of $30^{\circ} \mathrm{C}$ than that of $4^{\circ} \mathrm{C}$. In this study, the lower TF yields observed at $40^{\circ} \mathrm{C}$ and $50^{\circ} \mathrm{C}$ may be due to the inhibition of the enzymatic activity of $S$. venezuelae. S. venezuelae are soil bacteria and, therefore, achieve optimal growth and activity within the temperature range of $22^{\circ} \mathrm{C}-30^{\circ} \mathrm{C}$ [34]. Doull et al. [35] reported decreasing growth for $S$. venezuelae at temperatures higher than $37^{\circ} \mathrm{C}$ compared to that observed at a temperature of $27^{\circ} \mathrm{C}$. Based on the results obtained in this study, an incubation temperature within the range of $22^{\circ} \mathrm{C}-30^{\circ} \mathrm{C}$ is the preferred temperature for conducting the dehydrogenase test with TTC for $S$. venezuelae

\section{CONCLUSIONS}

The dehydrogenase activity test using triphenyl tetrazolium chloride (TTC) was employed to measure the growth and activity of Streptomyces venezuelae in MYM broth. The results showed high correlation between the absorbance and the TF yield. The effects of test parameters (incubation temperature, incubation time and medium $\mathrm{pH}$ ) were evaluated in order to determine the optimum test conditions. The three parameters significantly affected the TF yield. There also seem to be significant interactions between the medium $\mathrm{pH}$, incubation temperature and incubation time. In general, a $\mathrm{pH}$ of 6 gave the high TF yields and a $\mathrm{pH}$ of 9 gave higher TF yield. Lower TF yields were observed at $40^{\circ} \mathrm{C}$ and $50^{\circ} \mathrm{C}$ and higher yields occurred at $22^{\circ} \mathrm{C}$ and $30^{\circ} \mathrm{C}$ The increases in $\mathrm{TF}$ yield due to increase in incubation time were not significant. The recommended conditions for the reduction of TTC and the extraction of high amount of TF are 1 hour incubation at a temperature of $30^{\circ} \mathrm{C}$ and a me- 
dium $\mathrm{pH}$ of 6 followed by three extractions of TF with methanol.

\section{ACKNOWLEDGEMENTS}

The research was funded by National Science and Engineering Research Council (NSERC) of Canada.

\section{REFERENCES}

[1] Jakeman, D.L., Farrell, S., Young, W., Doucet, R.J. and Timmons, S.C. (2005) Novel and expanded jadomycins incorporating non-proteogenic amino acids. Bioorganic and Medicinal Chemistry Letters, 15, 5280-5283. doi:10.1016/j.bmcl.2005.08.047

[2] Zheng, J., Rix, U., Mattingly, C., Adams, V., Chen, Q., Rohr, J. and Yang, K. (2005) Cytotoxic activities of new jadomycin derivatives. Journal of Antibiotics, 58, 405408. doi:10.1038/ja.2005.51

[3] Burdock, T.J., Giffin, A.H., Brooks, M.S. and Ghaly, A.E. (2008) Heat balance analysis during the production of jadomycin C. American Journal of Biochemistry and Biotechnology, 4, 7-18. doi:10.3844/ajbbsp.2008.7.18

[4] Doull, J.L., Singh, A.K., Hoare, M. and Ayer, S.W. (1994) Conditions for the production of jadomycin B by Streptomyces venezuelae ISP5230: Effects of heat shock, ethanol treatment and phage infection. Journal of Industrial Microbiology, 13, 120-125. doi:10.1007/BF01584109

[5] Jakeman, D.L., Bandi, S., Graham, C.L., Reid, T.R., Wentzell, J.R. and Douglas, S.E. (2009) Antimicrobial activities of jadomycin B and structurally related analogues. Antimicrobial Agents and Chemotherapy, 53, 1245-1247. doi:10.1128/AAC.00801-08

[6] Jakeman, D.L., Graham, C.L., Young, W. and Vining, L.C. (2006) Culture conditions improving the production of jadomycin B. Journal of Industrial Microbiology and Biotechnology, 33, 767-772. doi:10.1007/s10295-006-0113-4

[7] Friedel, J.K., Molter, K. and Fischer, W.R. (1994) Comparison and improvement of methods for determining soil dehydrogenase activity by using triphenyltetrazolium chloride and iodonitrotetrazolium chloride. Biology and Fertility of Soils, 18, 291-296.

doi:10.1007/BF00570631

[8] Xie, J., Hu, W., Pei, H., Dun, M. and Qi, F. (2008) Detection of amount and activity of living algae in fresh water by dehydrogenase activity (DHA). Environmental Monitoring and Assessment, 146, 473-478. doi:10.1007/s10661-008-0250-5

[9] Chander, K. and Brookes, P.C. (1991) Is the dehydrogenase assay invalid as a method to estimate microbial activity in copper contaminated soils? Soil Biology and Biochemistry, 23, 909-915. doi:10.1016/0038-0717(91)90170-O

[10] Rogers, J.E. and Li, S.W. (1985) Effect of metals and other inorganic ions on soil microbial activity: Soil dehydrogenase assay as a simple toxicity test. Bulletin Environmental Contamination and Toxicology, 34, 858-865. doi:10.1007/BF01609817

[11] Yin, J., Liu, X. and Song, X. (2001) A method of extrac- tion at normal temperature for measurement of TTCdehydrogenase activity and its application. China Water and Wastewater, 17, 23-25.

[12] Beloti, V., Barros, M., de Freitas, J.C., Nero, L.A., De Souza, J.A., Santana, E.H.W. and Franco, B.D.G.M. (1998) Frequency of 2,3,5-triphenyltetrazolium chloride (TTC) non-reducing bacteria in pasteurized milk. Revista de Microbiologia, 30, 137-140. doi:10.1590/S0001-37141999000200009

[13] Mahmoud, N.S. and Ghaly, A.E. (2004) Influence of temperature and $\mathrm{pH}$ on the nonenzymatic reduction of triphenyltetrazolium chloride. Biotechnology Progress, 20, 346-353. doi: 10.1021/bp030029h

[14] Tarafdar, P.J.C. (2003) 2,3,5-Triphenyltetrazolium chloride (TTC) as electron acceptor of culturable soil bacteria, fungi and actinomycetes. Biology and Fertility of Soils, 38, 186-189. doi:10.1007/s00374-003-0600-y

[15] Ohara, M.T. and Saito, T. (1995) Application of triphenyltetrazolium chloride in microbial limit test of pharmaceuticals and cosmetics. Journal of AOAC International, 78, 1524-1529.

[16] Mahmoud, N.S. (2005) Novel biotechnological approach for the production of chitin and de-icing agents. Ph.D Thesis, Dalhousie University, Halifax.

[17] Burdock, T.J. (2009) Development of a dehydrogenase activity measurement test for Streptomyces venezuelae using triphenyl tetrazolium chloride. MSc. Thesis, Dalhousie University, Halifax.

[18] Ghaly, A.E., Kok, R., Ingrahm, J.M. (1989). Growth rate determination of heterogeneous microbial population in swine manure. Applied Biochemistry and Biotechnology, 22, 59-78. doi:10.1007/BF02922697

[19] Abdel-Fattah, Y.R. (2007) Application of fractional factorial design for the development of production media for the pikromycin macrolide family by Streptomyces venezuelae. Trends in Applied Science Research, 2, 472-482. doi:10.3923/tasr.2007.472.482

[20] Glazebrook, M, Doull, J.L., Stuttardan, C. and Vining, L.C. (1990) Sporulation of Streptomyces venezuelae in submerged cultures. Journal of General Microbiology, 136, 581-588.

[21] Backor, M. and Fahselt, D. (2005) Tetrazolium reduction as an indicator of environmental stress in lichens and isolated bionts. Environmental Experimental Botany, 53, 125-133. doi:10.1016/j.envexpbot.2004.03.007

[22] Jones, P.H. and Prasad, D. (1969) The use of tetrazolium salts as a measure of sludge activity. Water Pollution Control Federation, 41, R441-R449.

[23] Mersi, W.V. and Sehinne, F. (1991) An improved and accurate method for determining the dehydrogenase activity of soils with iodonitrotetrazolium chloride. Biology and Fertility of Soils, 11, 216-220. doi:10.1007/BF00335770

[24] Brzezińska, M., Stępniewska, Z. and Stępniewski, W. (2001) Dehydrogenase and catalase activity of soil irrigated with municipal wastewater. Polish Journal of Environmental Studies, 10, 307-311.

[25] Ghaly, A.E. and Ben-Hassan, R.M. (1993) Dehydrogenase activity measurement in yeast fermentation. Applied Biochemistry Biotechnology, 43, 77-91. doi:10.1007/BF02916434

[26] Ghaly, A.E. and Mahmoud, N.S. (2006) Optimum condi- 
tions for measuring dehydrogenase activity of Aspergillus niger using TTC. American Journal of Biochemistry and Biotechnology, 2,186-194. doi:10.3844/ajbbsp.2006.186.194

[27] Mahmoud, N.S. and Ghaly, A.E. (2006) Optimum condition for measuring dehydrogenase activity of Aspergillus niger using TTC. American Journal of Biochemistry and Biotechnology, 2, 186-194. doi:10.3844/ajbbsp.2006.186.194

[28] Mathew, M. and Obbard, J.P. (2001) Optimization of dehydrogenase activity measurements in beach sediments contaminated with petroleum hydrocarbons. Biotechnology Letters, 23, 227-230. doi:10.1023/A:1005613406948

[29] Tengerdy, R.P., Nagy, J.G. and Martin, B, (1967) Quantitative measurement of bacterial growth by the reduction of tetrazolium salts. Applied Microbiology, 15, 954-955.

[30] Griebe, T., Schaule, G. and Wuertz, S. (1997) Determination of microbial respiratory and redox activity in activated sludge. Journal of Industrial Microbiology and Biotechnology, 19, 118-122. doi:10.1038/sj.jim.2900431
[31] Trevors, J.T. (1984) Effect of substrate concentration, inorganic nitrogen, $\mathrm{O}_{2}$ concentration, temperature and $\mathrm{pH}$ on dehydrogenase activity in soil. Plant and Soil, 77, 285-293. doi:10.1007/BF02182931

[32] Tiquia, S.M., Wan, J.H.C. and Tam, N.F.Y. (2002) Dynamics of yard trimmings composting as determined by dehydrogenase activity. ATP content, arginine ammonification, and nitrification potential. Process Biochemistry, 37, 1057-1065. doi:10.1016/S0032-9592(01)00317-X

[33] Zhao, X., Li, H., Wu, Q., Li, Y., Zhao, C. and Zhang, Y. (2010) Analysis of dehydrogenase activity in phytoremediation of composite pollution sediment. 2nd Conference on Environmental Science and Information Application Technology (ESIAT 2010), Wuhan, 17-18 July 2010.

[34] Breed, R.S. (1957) Bergey's manual of determinative bacteriology. 7th Edition, Williams and Wilkins Company, Baltimore.

[35] Doull, J.L., Ayer, S.W., Singh, A.K. and Thibault, P. (1993) Production of a novel polyketide antibiotic, jadomycin B, by Streptomyces venezuelae following heat-shock. Journal of Antibiotics, 46, 869-871. 